\title{
THE EFFICIENCY ANALYSIS IN SMALL WINERIES IN THE REPUBLIC OF SERBIA
}

\author{
Nemanja Lekić1, Gordana Savić ${ }^{2}$, Snežana Knežević3, Aleksandra Mitrović ${ }^{4}$ \\ *Corresponding authorE-mail: nemanja.lekic@bbs.edu.rs
}

\begin{abstract}
A R T I C LE IN F O
A B S T R A C T

Review Article

Received: 05 September 2018

Accepted: 09 October 2018

doi:10.5937/ekoPolj1804529L

UDC 338.31:663.285(497.11)

Keywords:

Data envelopment analysis, Super-Efficiency, Efficiency, wineries, Republic of Serbia

JEL:C02, C43, C44, C55, C6, G30, $M 40$

This paper contains the attempt to evaluate the activity development efficiency of small wineries in the Republic of Serbia as insufficiently used development potential of one industry branch. Small wineries represent an activity which is currently being developed and it is expected that it will, as it is the case in developed countries, contribute to the total economic development and employment, development of brand as recognizable brand of wine from this region and start further recognizable development of this branch as family business in the country and abroad. The analysis was performed using the non-parametric linear programming model DEA (Data Envelopment Analysis). The aim of this paper is that, using the analysis of financial statements and the effectiveness of representative wineries belonging to the category of small enterprises, a rational strategic decision-making is provided.
\end{abstract}

(C) 2018 EA. All rights reserved.

\section{Introduction}

Wine growing in the Republic of Serbia is an important agricultural branch. On the one hand, it contributes to the economic progress of the entire country and on the other to the affirmation of rural areas and promotion of the areas where wine is produced. On the entire territory of the Republic of Serbia about 25,000 hectares are planted with the vines. The natural resources, climate, tradition and other allow its gradual revival and

1 Nemanja Lekić, Assistant, Belgrade Business School - Higher Education Institution for Applied Studies, Kraljice Marije 73, +381113042383, nemanja.lekic@bbs.edu.rs, https:// orcid.org/0000-0002-1559-6770

2 Gordana Savić, Associate Professor, University of Belgrade, Faculty of Organizational Sciences, Jove Ilića 154, 11000 Belgrade, Serbia, +381113950863, gordana.savic@fon. bg.ac.rs, https://orcid.org/0000-0001-6233-1815

3 Snežana Knežević, Associate Professor, University of Belgrade, Faculty of Organizational Sciences, Jove Ilića 154, 11000 Belgrade, Serbia, +381113950875, snezana.knezevic@fon. bg.ac.rs, https://orcid.org/0000-0003-0176-6107

4 Aleksandra Mitrović, Assistant Professor, University in Kragujevac, Faculty of Hotel Management and Tourism, Vojvođanska 5A, 36210 Vrnjačka Banja, Serbia, +381365150024, aleksandra.stankovic@kg.ac.rs, https://orcid.org/0000-0002-8302-0853

http://ea.bg.ac.rs 
rehabilitation in the coming years with at least 50 thousand hectares (Ivanišević, Jakšić \& Korać, 2015) (see also Lukić, Lalić, Sućeska, Hanić \& Bugarčić, 2018).

The subject of research are small wineries operating in the Republic of Serbia and their efficiency. The paper is based on a systematic and comparative analysis of the available scientific literature, as well as on the author's research results and experience in creating and implementing successful development strategy of small wineries based on the analysis of financial statements using the internal method of research. The research procedure was carried out on the basis of analysis of the contents of the primary and secondary sources, on the sample of 12 small wineries in Serbia, using financial statements according to official data from ABR (Agency for business registers). The evaluation of efficiency (super-efficiency) of the wineries was performed by applying the DEA model based on composite indicators. This paper will examine the influence of six indicators on the efficiency of the wineries, as follows: net working capital, retained earnings, EBIT (earnings before interest and taxes), the book value of capital, total assets and total debt. These analyzes will be carried out on concrete examples of small wineries as the representatives of small businesses whose development makes a strong link in the development of the manufacturing and processing industry of the Republic of Serbia.

The aim of the research is to obtain a clearer picture of the level of efficiency of local wineries using the analysis of efficiency among the representative wineries in Serbia, belonging to the category of small enterprises, that can enable a more rational strategic decision-making.

\section{Literature review}

A customary way of measuring the performance of financial systems is the use of indicators which are used for defining profitability, ratio of assets and liabilities, portfolio quality or efficiency. The efficiency consists of achieving as great as possible economic effects (output) with the smallest possible economic sacrifice (inputs) and is one of the most important principles of every business (Martić, 1999). Efficiency can be defined as the ability to achieve the desired goals with minimal use of available resources.

Starting from the inadequacy of the partial indicators such as labor productivity and capital productivity, Farrell (1957) proposed analytical procedure for measuring the effectiveness and evaluating the efficiency limits of production. Farrell considered a case when an organization uses multiple inputs and produces one output and assumed the constant return to scale. Some organization operates with constant returns to scale if an increase in its inputs results in a proportional increase in its outputs. Farrell introduced and defined the following three measures of efficiency: technical, allocative and overall efficiency.

According Koopmans' definition of technical efficiency (Koopmans, 1951) a manufacturer is technically efficient if and only if it is not able to increase production of some of the outputs without reducing the production of another output or usage of larger amounts of 
one of the inputs. Efficiency of the allocation of resources is expressed as a percentage, where $100 \%$ indicates that the organization appropriately uses the inputs so as to minimize the cost of manufacture. An organization that is efficient in the engineering (technical) terms may be allocatively inefficient, since it does not use the inputs in the appropriate proportion with respect to the given prices (Savić, 2012). The overall efficiency combines technical and allocative efficiency. An organization can be cost-efficient only if it is the technically and allocatively efficient. Overall efficiency is calculated as the product of technical and allocative efficiency (expressed in percentages). It means that the organization can achieve cost-efficiency of $100 \%$ only if the technical efficiency is equal to $100 \%$ and the efficiency of resource allocation equal to $100 \%$.

To achieve more efficient management of payables wineries should consider the need to conduct a range of activities, such as (Knežević \& Fabris, 2010): improvement of information systems that will improve the quality of information used in the analysis of working capital; defining and monitoring of key performance indicators (level of obligations with respect to the operational costs, the average period of collection, age-structure of the obligations and the like); defining adequate policy, procedures and control mechanisms for payables management; considering the possibilities of reducing the number of suppliers of the same product group in order to ensure more favorable conditions for procurement (lower prices and longer credit period), as well as the implementation of adequate policy related to the selection of suppliers which aims at selecting and doing business with companies that are reliable and have a good reputation (see also Mitrović, Knežević \& Veličković, 2015).

Data envelopment analysis (DEA) is the approach of non-parametric linear programming, which allows processing of multiple inputs and multiple outputs (Paradi, Asmild, Aggarwall \& Schaffnit, 2004) or the simultaneous analysis of different types of inputs and outputs. DEA model can be constructed either to minimize the inputs or to maximize the outputs. In the input-oriented model efficacy is enhanced through a proportional reduction in the input and output orientation requires proportionate increase of the output (Cooper, Seiford \& Tone, 2000). DEA is a tool for measuring and monitoring the effectiveness of organizational performance. Organizational units of DMU (Eng. Decision Making Unit) are defined as the units to be decided on (Savić, 2012). This name was introduced to show that the DEA can be used to measure the effectiveness of different types of entities, which operate in a similar manner. In addition, it can be concluded how much it is necessary to reduce the specific input and/ or increase the specific output to make these units become efficient.

In the literature relatively low attention has been paid on how these inputs and outputs should be selected. Some authors treat the input and output variables in their studies as "the given" and then they move on to the methodology itself. Others use statistical methods (e.g., regression and correlation analysis) as assistance in the reduction of the number of criteria. The selection of DEA model and choice of input and output variables depends on the aim and purpose, but also on each individual case. 
From the methodological point of view (Sellers-Rubio, Alampi-Sottini \& Menghini, 2016) defining the inputs and outputs is one of the main problems that arise in the assessment of efficiency in the wine industry. In this respect, when comparing relative performance of wine producers, it is possible to take into account the technical perspective, which analyzes the ability of a winery to transform certain volumes of the inputs to as great as possible outputs (e.g., liters of wine) or to analyze the ability to transform some inputs to the output values (e.g., sale). The first approach is called the concept of technical efficiency, while the second approach is considered as the economic concept of efficiency. In accordance with the principles of DEA for measuring the efficacy of wineries often selected are the input and output parameters (variables) on the basis of previous studies of the authors and the recommendations from the scientific literature (Sellers \& Alampi-Sottini, 2016). These authors conducted a study on the analysis of the size of the wineries on their economic performance on the territory of Italy. The results showed a positive and statistically significant correlation relationship between size and profitability of the wineries. Larger wineries have greater negotiating power with its stakeholders, as well as easier access to international markets. Likewise, smaller wineries have great technical and commercial opportunities.

A composite indicator is an aggregate index, containing individual parameters and their corresponding weight coefficients. It was created by UNDP (2000), as a sum indicator of human development index (HDI). The HDI index is an average measure of basic achievements in terms of human development in a country: age, knowledge and standard of living. It measures the multidimensional concepts that cannot be captured by one indicator. The system of forming weight coefficients may be based on DEA method.

Therefore, the DEA models need to be modified by introducing Dummy variables equal to 1 and several outputs with normalized or raw data, in order to cover the composite indicators. Each sub-component within the DEA analysis is seen as the input, since an increase in its value favors the observed financial book values. That is why Melyn \& Moesen (1991) and Cherchye et al. (2007) created a special class of models called "benefit of the doubt". This model can mathematically be expressed as follows (Shen, Ruan, Hermans, Brijs, Wets \& Vanhoof, 2011):

$$
(\max ) h_{k}=\sum_{r=1}^{s} u_{r} y_{k}
$$

a.c.

$$
\begin{aligned}
& \sum_{r=1}^{s} u_{r} y_{k} \leq 1, \quad j=1, \ldots, n \\
& u_{1}, \ldots u_{s} \geq 0
\end{aligned}
$$

where: $h_{k}$-relative efficiency of the $k$-th DMU; $n$ - the number of DMU to be compared; $m$ - number of inputs; $s$ - number of outputs; $u_{r}$ - weight coefficient for the output $r$; $v_{i}$ - weight coefficient for the input $i$. 


\section{Data on wine production in Serbia and methodology used in research}

\section{Data on wine production in Serbia}

The starting point of research consists of statistical data on the production of wine. In Table 1, ranking of wine producers is performed. The largest wine producer in the world in 2015 was Italy with 48,9 million hl produced. It is followed by France with $47,4 \mathrm{mhl}$. Serbia is on the 19th place with 2,3 million hectoliters of wine produced. If we look at Europe, first four places occupy Italy $(48,9 \mathrm{mhl})$, followed by France $(47,4$ mhl), Spain (36.6 mhl) and Germany (8,8 mhl) (OIV, 2015).

Table 1. Production of wine (excluding juice and musts) (1)

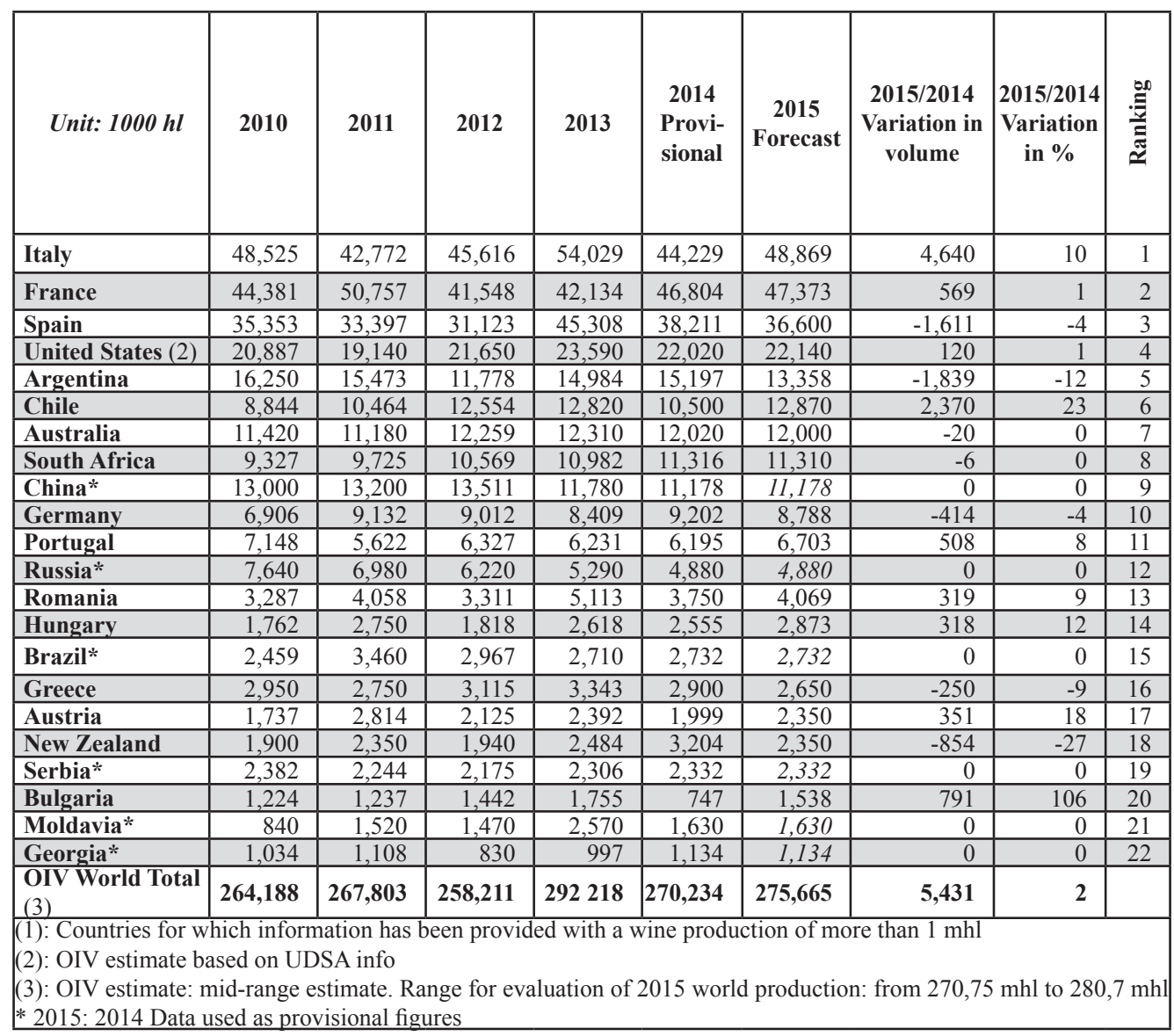

Source: The International Organization of Vine and Wine (OIV)

According to currently available data, in 2014 Serbia produced 198,183,000 liters of wine. This is by 71,783,000 liters more than in 2012 and by 39,863,000 liters less than in 2009 when it produced the most wine in the reporting period from 2009 to 2014, as shown in Table 2. 
Table 2. Total wine production in Serbia from 2009 to 2014

\begin{tabular}{|c|c|}
\hline Year & Wine production in [I] \\
\hline 2009 & $238,046,000$ \\
\hline 2010 & $148,753,700$ \\
\hline 2011 & $158,084,500$ \\
\hline 2012 & $126,400,000$ \\
\hline 2013 & $145,283,700$ \\
\hline 2014 & $198,183,000$ \\
\hline
\end{tabular}

Source: Wine Atlas, 2015

According to data from the Wine registry from 01.01.2014, the number of large wineries in Serbia with more than 250 employees is small, only two wineries. Belonging to medium-sized wineries having from 50 to 249 employees is only one winery; although, by the quantity of produced wines, it occupies a large share of total production. There are 23 small wineries, with the number of employees from 10 to 49. Micro wineries, with less than 10 employees make up the largest group of wine producers in Serbia and there are 191 (Jakšić, Ivanišević, Đokić \& Brbaklić-Tepavac, 2015).

The largest Serbian wineries distribute their wine in Serbia and in some countries in the region through an independent distribution network, consisting of offices in major cities in Serbia (Belgrade, Novi Sad, Niš, Kragujevac, etc.), HoReCa, managers for capillary sales, etc. Distribution of wine to the end consumers usually takes place directly through the wholesale and retail trade of consumer goods chains, distributors, wine shops and catering facilities (restaurants, cafes, hotels, motels, rural tourism facilities, etc.) (Jakšić, Ivanišević, Đokić \& Brbaklić-Tepavac, 2015). The smallest part of wine is distributed directly to end consumers in the wineries themselves, when consumers, as tourists, visit the wineries (the wine routes, catering, etc.). In order to include the traditional family wineries in Serbia in tourism development, they should be enriched by catering facilities. This is primarily related to the organization of the hall for wine tasting as part of a family farm or winery (Jovanović, Muhi \& Anđelković, 2015). In this way, owners of wineries would enable potential tourists the tour of the winery and wine tasting.

Table 3. Exports of wines of Serbia by markets [1]

\begin{tabular}{|c|c|c|c|c|}
\hline Year & CEFTA & \multicolumn{1}{|c|}{ EU } & Other markets & \multicolumn{1}{c|}{ Total } \\
\hline 2009 & $\mathbf{6 , 9 7 1 , 8 3 1}$ & $\mathbf{6 4 2 , 0 9 9}$ & $\mathbf{2 , 7 7 2 , 7 5 2}$ & $\mathbf{1 0 , 3 8 6 , 6 8 2}$ \\
\hline 2010 & $\mathbf{5 , 9 0 6 , 3 6 6}$ & $\mathbf{1 , 3 2 0 , 1 9 5}$ & $\mathbf{3 , 5 3 4 , 8 7 7}$ & $\mathbf{1 0 , 7 6 1 , 4 3 8}$ \\
\hline 2011 & $\mathbf{5 , 5 1 6 , 6 6 2}$ & $\mathbf{5 , 6 6 7 , 3 8 0}$ & $\mathbf{4 , 1 3 0 , 7 0 0}$ & $\mathbf{1 5 , 3 1 4 , 7 4 2}$ \\
\hline 2012 & $\mathbf{4 , 7 4 2 , 4 7 9}$ & $\mathbf{1 4 , 1 1 8 , 3 8 4}$ & $\mathbf{3 , 9 3 0 , 1 8 8}$ & $\mathbf{2 2 , 7 9 1 , 0 5 1}$ \\
\hline 2013 & $\mathbf{4 , 3 5 7 , 7 4 3}$ & $\mathbf{2 , 0 4 8 , 2 0 9}$ & $\mathbf{5 , 0 7 1 , 7 6 9}$ & $\mathbf{1 1 , 4 7 7 , 7 1 2}$ \\
\hline 2014 & $\mathbf{5 , 1 3 6 , 7 1 9}$ & $\mathbf{5 5 9 , 9 0 9}$ & $\mathbf{6 , 2 4 4 , 8 9 3}$ & $\mathbf{1 1 , 9 4 1 , 5 2 2}$ \\
\hline
\end{tabular}

Source: Wine Atlas, 2015

As regards exports of wine in 2014 Serbia recorded the exports amounting to 11,941,522 liters of wine which is 10,849,529 less than in 2012 when it recorded the highest exports observed since 2009 , but more by $1,554,840$ than in 2009 when it exported 10,386,682 liters of wine (Table 3). 


\section{Methodology used in the research}

Due to the fact that in the conditions of intensive development and increasing competition it is often necessary to make mutual comparison of efficient organizations, several approaches are developed for the full ranking of all units. One method of ranking based on DEA efficiency evaluation is a model for the evaluation of super-efficiency that assumes DEA modification of the model so that index greater than 1 can be assigned to efficient units and thus enable the discrimination between them. Andersen and Petersen (1993) proposed a modified DEA model which enables ranking efficient units, i.e. super-efficiency score. Analogously to the proposed model modification of the models (1) - (3) can be made so as to provide a ranking on the basis of the composite indicator (Savić \& Martić, 2016):

$$
\begin{aligned}
& (\max ) h_{k}=\sum_{r=1}^{s} u_{r} y_{k} \\
& \text { a.c. } \\
& \sum_{r=1}^{s} u_{r} y_{\dot{j}} \leq 0, \quad j=1, \ldots, n, j \neq k \\
& u_{1}, \ldots u_{s} \geq 0, v_{1}, \ldots v_{m} \geq 0
\end{aligned}
$$

The presented modified model allows ranking of the efficiency units similarly as the inefficient units based on the index greater than or equal 1.

Using the data envelopment analysis the efficiency of 12 wineries (DMU) will be performed, which according to the number of employees belong to the category of small enterprises for 2014 and 2015. The production process of the wineries is perceived as a black box in which it is taken that we have a single input with an efficiency of 1 , and the output efficiency is viewed through six indicators (Table 4): net working capital, retained earnings, EBIT (earnings before interest and taxes), the book value of capital, total assets and total debt:

$$
(\max ) h_{k}=\sum_{r=1}^{6} u_{r} y_{k}
$$

a.c.

$$
\begin{aligned}
& \sum_{r=1}^{6} u_{r} y_{r j} \leq 0, \quad j=1, \ldots, 12, j \neq k \\
& u_{1}, \ldots u_{6} \geq 0, \quad v_{1}, \ldots v_{m}=1
\end{aligned}
$$


Table 4. Model of super efficiency with six outputs

\begin{tabular}{|l|l|l|}
\hline \multicolumn{2}{|c|}{ Outputs } & \multicolumn{2}{c|}{ Description } \\
\hline 1 & $\begin{array}{l}\text { Net working } \\
\text { capital }\end{array}$ & $\begin{array}{l}\text { Five positions from the balance sheet: (Capital + Long term reservations and } \\
\text { liabilities - reported but unpaid capital - Loss above equity) - Non-current } \\
\text { assets }\end{array}$ \\
\hline 2 & $\begin{array}{l}\text { Retained } \\
\text { earnings }\end{array}$ & $\begin{array}{l}\text { Three positions from the balance sheet: Retained earnings - Loss - Loss in } \\
\text { excess of capital }\end{array}$ \\
\hline 3 & EBIT & Two positions from the income statement: Operating profit - Operating loss \\
\hline 4 & $\begin{array}{l}\text { Bookkeeping } \\
\text { value of capital }\end{array}$ & $\begin{array}{l}\text { Five positions from the balance sheet: Capital - loss in excess of capital - } \\
\text { reported but unpaid capital - Deferred tax assets + Deferred tax liabilities }\end{array}$ \\
\hline 5 & Total assets & $\begin{array}{l}\text { Two positions from the balance sheet: Operating assets- Reported but unpaid } \\
\text { capital }\end{array}$ \\
\hline 6 & Total debt & Two positions from the balance sheet: Long term reservations and obligations \\
\hline
\end{tabular}

Source: The authors' calculations

As indicators in this analysis, we have taken the ones from Financial reports for the years 2014 - 2015, more precisely:

1) Net working capital as a measure of the company's ability to finance average stocks and new investments. Net working fund is the difference of the greater value of long term funding sources (capital, long-term loans...) in relation to the values of long-term property that is used in performance of the activity (real estate, plants and equipment...). The available amount of net working capital must be minimum equal to the average stocks. The lack of funds of the Net working capital points out that there is a problem in maintaining the current liquidity in business, while the excess of Net working fund above average stocks can be invested in new investments (own participation).

2) Retained earnings is a part of the capital in cumulated non-distributed gain and it represents a measure of proceeds to the invested property and/or capital in performance of activity.

3) EBIT is the gain of the current period enlarged by the income tax and interest costs. In developed countries, this indicator is often used as a measure of success in current business through which we measure the ability of the company to pay debts back. In developing countries, this indicator should be corrected by the amount of financing costs having in mind that, as a rule, they are rather high, and thus regardless of recording them as the expense in the profit and loss statement, they should not be qualified as a part of operating cash flow.

4) Bookkeeping value of capital is the value of the Share capital (equity) and the other capital. It represents a guarantee to the creditors and the measure of company's ability for self-financing.

5) Total assets consists of main and working funds for performing the manufacturing and selling of wine. 
6) Total liabilities (debt) are the obligations from commercial or finance transactions.

Indicators that were previously listed and explained are included in the model in order to determine the correlation of the proceeds (Retained earnings) from the property and/ or capital, earnings before interests and taxes (EBIT) in relation to the obligations taken and Net working capital as a constant and indicator of mutual relations of indicators in the model having in mind that Net working capital represents an available amount of working capital (source of working funds).

\section{Results and discussion}

It is common that in financial analyses operating parameters of companies in the last three years are compared. Since this paper analyzes the economic activity of small wineries whose development is especially present in the last two years, with the specific companies the last two years will be analyzed for the parameters of analysis to be consistent. Still dominating are the companies of entrepreneurs because, on the one hand in accordance with the regulations of the Republic of Serbia organizing entrepreneurial activities is easier, and on the other hand, according to the tax regulations, this kind of organization of performing economic activity is more stimulating (e.g. the possibility of lump-sum taxation, lower tax rates, etc.). General data of the wineries that are subject of the analysis are shown in Table 5.

Table 5. General information on companies analyzed

\begin{tabular}{|c|c|c|c|c|c|c|c|c|}
\hline $\begin{array}{l}\text { Or. } \\
\text { no }\end{array}$ & Name of winery & $\begin{array}{l}\text { Y. of } \\
\text { estab }\end{array}$ & $\begin{array}{l}\text { Wine- } \\
\text { growing } \\
\text { region }\end{array}$ & $\begin{array}{l}\text { Wine } \\
\text { growing } \\
\text { district }\end{array}$ & $\begin{array}{c}\text { Aver. } \\
\text { no of } \\
\text { employ. }\end{array}$ & $\begin{array}{l}\text { Vineyard } \\
\text { area [ha] }\end{array}$ & $\begin{array}{l}\text { Annual wine } \\
\text { production[1] }\end{array}$ & $\begin{array}{l}\text { No. reg. } \\
\text { labels }\end{array}$ \\
\hline 1. & PIK Oplenac LLC Topola & $1956^{*}$ & Šumadija & Oplenac & 16 & 47,00 & 700,000 & 11 \\
\hline 2. & $\begin{array}{l}\text { "PODRUM } \\
\text { RADOVANOVIĆ" LLC } \\
\text { Krnjevo }\end{array}$ & 1996 & Šumadija & Krnjevac & 11 & 25,00 & 280,000 & 14 \\
\hline 3. & $\begin{array}{l}\text { PTK “KLJUČ" SC Kladovo } \\
\text { (trade name "Vinarija } \\
\text { Duša") }\end{array}$ & 2007 & $\begin{array}{c}\text { Negotinska } \\
\text { Krajina }\end{array}$ & Ključko & 31 & 40,07 & 30,000 & 2 \\
\hline 4. & "STATUS" LLC Svrljig & 1997 & $\mathrm{Nišs}$ & Svrljig & 36 & 15,36 & $1,000,000$ & 12 \\
\hline 5. & $\begin{array}{l}\text { Radiša Mladenović } \\
\text { entrepreneur "MATALJ" } \\
\text { Negotin }\end{array}$ & 2008 & $\begin{array}{c}\text { Negotinska } \\
\text { Krajina }\end{array}$ & Negotin & 43 & 17,00 & 55,000 & 11 \\
\hline 6. & $\begin{array}{l}\text { "TOPLIČKI VINOGRADI" } \\
\text { LLC Gojinovac }\end{array}$ & 2008 & Toplica & Prokuplje & 12 & 35,00 & 93,000 & 9 \\
\hline 7. & $\begin{array}{l}\text { "VINARIJA } \\
\text { ALEKSANDROVIĆ" LLC } \\
\text { Vinča }\end{array}$ & 2004 & Šumadija & Oplenac & 19 & 69,26 & 300,000 & 19 \\
\hline 8. & $\begin{array}{l}\text { "VINARIJA ALEKSIĆ"، } \\
\text { LLC Vranje }\end{array}$ & 2006 & Vranje & Vrtogoško & 12 & $2,50 * * *$ & 150,000 & 10 \\
\hline 9. & $\begin{array}{l}\text { Bogunović LLC Beograd } \\
\text { (Zemun) }\end{array}$ & 2010 & VIVR** & - & 28 & 2,20 & 60,000 & 6 \\
\hline
\end{tabular}




\begin{tabular}{|c|l|c|c|c|c|c|c|c|}
\hline $\begin{array}{c}\text { Or. } \\
\text { no }\end{array}$ & \multicolumn{1}{|c|}{ Name of winery } & $\begin{array}{c}\text { Y. of } \\
\text { estab } \\
\text { growing } \\
\text { region } \\
\text { growing } \\
\text { district }\end{array}$ & $\begin{array}{c}\text { Wine- } \\
\text { no of } \\
\text { employ. }\end{array}$ & $\begin{array}{c}\text { Wineyard } \\
\text { area [ha] }\end{array}$ & $\begin{array}{c}\text { Annual wine } \\
\text { production[I] }\end{array}$ & $\begin{array}{c}\text { No. reg. } \\
\text { labels }\end{array}$ \\
\hline 10. & $\begin{array}{l}\text { LLC "VINARIJA } \\
\text { KOVAČEVIĆ“ Irig }\end{array}$ & 2003 & Srem & $\begin{array}{c}\text { Fruška } \\
\text { gora }\end{array}$ & 23 & 84,00 & $1,000,000$ & 13 \\
\hline 11. & $\begin{array}{l}\text { "VINARIJA ZVONKO } \\
\text { BOGDAN“ LLC Subotica }\end{array}$ & 1989 & Subotica & Palić & 18 & 50,00 & 133,000 & 11 \\
\hline 12. & $\begin{array}{l}\text { "VINEX GROZD" LLC } \\
\text { Belušić }\end{array}$ & 2008 & $\begin{array}{c}\text { Three } \\
\text { Moravas }\end{array}$ & Levač & 37 & 35,00 & - & 12 \\
\hline $\begin{array}{l}* \\
* *\end{array}$ \\
$* * *$ Winformed privatization, renovated winery opened in 2015 \\
$*$ in cooperation
\end{tabular}

Source: Adapted to the study: Wine Atlas, 2015

Descriptive statistics for variables performance that was used for the analysis in 2014 is given in Table 6 . The correlation between the observed performances is shown in Table 7 .

Table 6. Descriptive statistics in the profit model of super efficiency in 2014 in thousands of RSD

\begin{tabular}{|l|r|r|r|r|r|r|}
\hline $\begin{array}{c}\text { Statistics } \\
\text { (2014) }\end{array}$ & $\begin{array}{c}\text { Net working } \\
\text { capital }\end{array}$ & $\begin{array}{c}\text { Retained } \\
\text { earning }\end{array}$ & EBIT & $\begin{array}{c}\text { Bookkeeping } \\
\text { value of capital }\end{array}$ & Total assets & Total debt \\
\hline Maximum & 612,161 & 584,345 & 86,711 & 546,786 & 947,944 & 0.000075 \\
\hline Minimum & 0 & 0 & 0 & 0 & 32,428 & 0.000002 \\
\hline Medium & $353,693,4$ & $264,922,1$ & $36,252,75$ & $226,056,7$ & $321,250,9$ & 0.000022 \\
\hline S.D. & $167,380,2$ & 174,806 & $24,414,87$ & $163,867,3$ & $253,013,5$ & 0.000026 \\
\hline
\end{tabular}

Source: The authors' calculations

Table 7. Correlation of analyzed performance in 2014

\begin{tabular}{|l|r|r|r|r|r|r|}
\hline & \multicolumn{1}{|c|}{$\begin{array}{c}\text { Net } \\
\text { working } \\
\text { capital }\end{array}$} & $\begin{array}{l}\text { Retained } \\
\text { earnings }\end{array}$ & EBIT & $\begin{array}{c}\text { Bookkeeping } \\
\text { value of } \\
\text { capital }\end{array}$ & $\begin{array}{c}\text { Total } \\
\text { assets }\end{array}$ & $\begin{array}{c}\text { Total } \\
\text { debt }\end{array}$ \\
\hline Input & 0 & 0 & 0 & 0 & 0 & 0 \\
\hline Net working capital & 1 & 0.31100 & 0.60419 & 0.19136 & -0.50594 & 0.51810 \\
\hline Retained earnings & 0.31100 & 1 & 0.58571 & 0.92130 & 0.51101 & 0.04004 \\
\hline EBIT & 0.60419 & 0.58571 & 1 & 0.67810 & 0.26279 & -0.12607 \\
\hline $\begin{array}{l}\text { Bookkeeping value } \\
\text { of capital }\end{array}$ & 0.19136 & 0.92130 & 0.67810 & & 0.68955 & -0.14652 \\
\hline Total assets & -0.50594 & 0.51101 & 0.26279 & 0.68955 & 1 & -0.53997 \\
\hline Total debt & 0.51810 & 0.04004 & -0.12607 & -0.14652 & -0.53997 & 1 \\
\hline
\end{tabular}

Source: The authors' calculations 
Based on the analysis of descriptive statistics, data obtained for 2014 and as shown in Table 6 by observing the values of the standard deviation it is observed that the highest deviation from the mean value is in the case of total asset, which is in accordance with the drastically different values of production facilities and the number of plantings, as shown in Table 5.

Table 8. Descriptive statistics in the profit model of super efficiency in 2015 in thousands of RSD

\begin{tabular}{|l|r|r|r|r|r|r|}
\hline $\begin{array}{c}\text { Statistics } \\
\text { (2015) }\end{array}$ & $\begin{array}{c}\text { Net working } \\
\text { capital }\end{array}$ & $\begin{array}{c}\text { Retained } \\
\text { earnings }\end{array}$ & EBIT & $\begin{array}{c}\text { Bookkeeping } \\
\text { value of } \\
\text { capital }\end{array}$ & Total assets & Total debt \\
\hline Maximum & 600,720 & 775,822 & 92,612 & 771,092 & $1,098,132$ & 0.00008 \\
\hline Minimum & 0 & 0 & 0 & 0 & 56,061 & 0.00000 \\
\hline Medium & $388,317,3$ & $305,597,3$ & $30,305,92$ & $256,026,9$ & $371,362,5$ & 0.00002 \\
\hline S.D. & $149,562,6$ & $211,453,6$ & $28,687,17$ & $210,865,2$ & $259,842,1$ & 0.00002 \\
\hline
\end{tabular}

Source: The authors' calculations

Table 9. Correlation of analyzed performance in 2015

\begin{tabular}{|l|c|c|c|r|c|c|}
\hline & $\begin{array}{c}\text { Net } \\
\text { working } \\
\text { capital }\end{array}$ & $\begin{array}{l}\text { Retained } \\
\text { earnings }\end{array}$ & EBIT & $\begin{array}{c}\text { Bookkeeping } \\
\text { value of capital }\end{array}$ & $\begin{array}{c}\text { Total } \\
\text { assets }\end{array}$ & Total debt \\
\hline Input & 0 & 0 & 0 & 0 & 0 & 0 \\
\hline $\begin{array}{l}\text { Net working } \\
\text { capital }\end{array}$ & 1 & 0.49053 & 0.38179 & 0.36572 & -0.26729 & 0.40533 \\
\hline $\begin{array}{l}\text { Retained } \\
\text { earnings }\end{array}$ & 0.49053 & & 0.54834 & 0.96997 & 0.66618 & -0.03656 \\
\hline EBIT & 0.38179 & 0.54834 & 1 & 0.54335 & 0.27992 & -0.19551 \\
\hline $\begin{array}{l}\text { Bookkeeping } \\
\text { value of capital }\end{array}$ & 0.36572 & 0.96997 & 0.54335 & & 0.75023 & -0.06833 \\
\hline Total assets & -0.26729 & 0.66618 & 0.27992 & 0.75023 & & -0.42992 \\
\hline Total debt & 0.40533 & -0.03656 & -0.19551 & -0.06833 & -0.42992 & 1 \\
\hline
\end{tabular}

Source: The authors' calculations

By analyzing the data obtained by descriptive statistics for 2015 and presented in Table 8 , we can see that the values of the standard deviation show the highest deviation from the mean value in the case of total assets, as was the case in the previous year.

In line with the general trend of improving macroeconomic activity of RS sector of production and processing of wine, in 2015 it recorded better performance compared to 2014. With further growth of liquidity and improvement of the companies' efficiency, the improvement of analyzed performance measures is also expected in the future. 
The analysis of Pearson's correlation coefficients in 2014 and 2015 is presented in Tables 7 and 9 showing the strongest correlation between the ratio of retained earnings and book value of equity of 0.92 and 0.97 respectively, which indicates almost concurring movement of these two values. The amount of total assets and the total amount of debt showed the strongest negative correlation ratio of -0.54 and -0.43 respectively in the observed years.

Based on the observed effect of the wineries in 2014 and 2015, super-efficiency for each winery is calculated, as shown in Tables 10 and 11. In order to calculate the overall efficiency results we used output-oriented DEA model of composite indicators (Model Name = DEA-Solver Pro. V13.0/ Super-Radial (Super-CCR-O) Returns to Scale = Constant $(0=<$ Sum of Lambda $<$ Infinity), whereat the input is 1 and the outputs are: net working capital, retained earnings, EBIT (earnings before interest and taxes), the book value of capital, total assets and total debt.

Table 10. Super-efficiency according to the DEA model of composite indicators in 2014

\begin{tabular}{|c|c|c|}
\hline Rank & Name of the winery & Score \\
\hline 1 & "VINARIJA ZVONKO BOGDAN" LLC Subotica & 1.91111 \\
\hline 2 & LLC "VINARIJA KOVAČEVIĆ" Irig & 1.55419 \\
\hline 3 & "PODRUM RADOVANOVIĆ" LLC Krnjevo & 1.38527 \\
\hline 4 & "TOPLIČKI VINOGRADI" LLC Gojinovac & 1.06610 \\
\hline 5 & "VINEX GROZD" LLC Belušić & 0.85714 \\
\hline 6 & "STATUS" LLC Svrljig & 0.83851 \\
\hline 7 & "VINARIJA ALEKSANDROVIC" LLC Vinča & 0.80149 \\
\hline 8 & PTK “KLJUC" SC Kladovo & 0.72130 \\
\hline 9 & PIK Oplenac LLC Topola & 0.61669 \\
\hline 10 & "VINARIJA ALEKSIĆ" LLC Vranje & 0.57640 \\
\hline 11 & Bogunović LLC Beograd (Zemun) & 0.56815 \\
\hline 12 & Radiša Mladenović entrepreneur "MATALJ" Negotin & 0.53718 \\
\hline
\end{tabular}

Source: The authors' calculations

Table 11. Super-efficiency according to the DEA model of composite indicators in 2015

\begin{tabular}{|c|l|c|}
\hline Rank & \multicolumn{1}{|c|}{ Name of the winery } & Score \\
\hline 1 & "VINARIJA ZVONKO BOGDAN“ LLC Subotica & $\mathbf{2 . 2 0 1 0 4}$ \\
\hline 2 & LLC "VINARIJA KOVAČEVIĆ“ Irig & 1.41125 \\
\hline 3 & "TOPLIČKI VINOGRADI“ LLC Gojinovac & 1.21654 \\
\hline 4 & "PODRUM RADOVANOVIĆ” LLC Krnjevo & $\mathbf{1 . 2 1 4 9 5}$ \\
\hline 5 & "VINEX GROZD“ LLC Belušić & $\mathbf{0 . 9 3 5 9 5}$ \\
\hline 6 & "VINARIJA ALEKSANDROVIC“ LLC Vinča & $\mathbf{0 . 8 3 0 6 2}$ \\
\hline 7 & "STATUS" LLC Svrljig & $\mathbf{0 . 7 3 1 5 2}$ \\
\hline
\end{tabular}




\begin{tabular}{|c|l|c|}
\hline Rank & \multicolumn{1}{|c|}{ Name of the winery } & Score \\
\hline 8 & PTK “KLJUC" SC Kladovo & $\mathbf{0 . 6 8 2 4 7}$ \\
\hline 9 & PIK Oplenac LLC Topola & $\mathbf{0 . 6 5 8 4 8}$ \\
\hline 10 & "VINARIJA ALEKSIĆ“ LLC Vranje & $\mathbf{0 . 6 2 7 3 6}$ \\
\hline 11 & Bogunović LLC Beograd (Zemun) & $\mathbf{0 . 5 2 7 7 1}$ \\
\hline 12 & Radiša Mladenović entrepreneur "MATALJ" Negotin & $\mathbf{0 . 5 1 6 2 3}$ \\
\hline
\end{tabular}

Source: The authors' calculations

According to data from Tables 10 and 11 in 2014 and 2015, the dominant position in terms of super-efficiency realized the "VINARIJA ZVONKO BOGDAN" LLC Subotica with a score of 1.91 and 2.2 respectively. If the mentioned score obtained is observed independently of the liquidity ratio and turnover ratio it can blur the image on the performance of the enterprise to creditors. For this reason, decision-making is not advised based solely on the assessment of super-efficiency without the traditional analysis of fundamental indicators.

In further analysis, we grouped wineries into three categories: with the index of the super-efficiency lower than $60 \%$, with the index in the range of from $61 \%$ to $99 \%$ and the index greater than $100 \%$, Table 12 .

Table 12. Index of super-efficiency of small wineries

\begin{tabular}{|c|r|r|r|r|r|r|}
\hline \multirow{2}{*}{ Statistics } & \multicolumn{3}{|c|}{2014} & \multicolumn{3}{|c|}{2015} \\
\cline { 2 - 7 } & Frequency & Percentage & $\begin{array}{c}\text { Cumulative } \\
\text { percentage }\end{array}$ & Frequency & Percentage & $\begin{array}{c}\text { Cumulative } \\
\text { percentage }\end{array}$ \\
\hline eff $<60 \%$ & 3 & $25.00 \%$ & $25.00 \%$ & 2 & $16.67 \%$ & $16.67 \%$ \\
\hline $\begin{array}{c}61 \%<\mathrm{eff}< \\
99 \%\end{array}$ & 5 & $41.67 \%$ & $66.67 \%$ & 6 & $50.00 \%$ & $66.67 \%$ \\
\hline$>100 \%$ & 4 & $33.33 \%$ & $100.00 \%$ & 4 & $33.33 \%$ & $100.00 \%$ \\
\hline
\end{tabular}

Source: The authors' calculations

Based on the data in table 12, there is a tendency of increasing the index of superefficiency of wineries from the zone $61 \%$ to $99 \%$, for $20 \%$.

\section{Conclusion}

Wine growing and enology may represent a significant part of the development potential of Serbia and thus, more attention should be paid on the industry.

By optimizing working capital wineries affect the reduction of the level of employed capital, release financial resources faster, increase liquidity, and therefore increase the overall value of the company. If wineries are successful in optimizing receivables and inventories they will achieve greater efficiency. In practice, it is difficult to achieve an optimal level of receivables and inventories and therefore companies often resort to the deferment of payment of their due debts. Financial indicators cannot directly provide answers to important questions about a winery, but on the basis of the relationship between the obtained indicators, comparing achieved performance and certain operating standards, we have identified certain differences and variations. 
For making optimal decisions it is necessary to look at different aspects of the analysis. In fact, without the analysis of fundamental ratios it is not possible to make an unambiguous conclusion by the application of solely DEA model.

To obtain a true image of the efficiency of the wineries the research should be expanded on the wineries that belong to micro enterprises which are the most numerous in the Republic of Serbia. Therefore, to the stakeholders in the emerging markets it is recommended that analyses are not performed individually, but using a multidimensional coverage of various performance measures of the companies.

Winery owners need to keep in mind that if they want to achieve good results they have to engage managers who know that with the help of various tools of financial analysis they can get an abundance of useful information out of the financial statements relevant to the success of the wineries. Top management of the wineries is the one that should initiate appropriate measures which may lead to the performance correction of wineries.

\section{Conflict of interests}

The authors declare no conflict of interest.

\section{References}

1. Andersen, P., \& Petersen, N. C. (1993). A procedure for ranking efficient units in data envelopment analysis. Management Science, 39(10), 1261-1274.

2. Cherchye, L., Moesen, W., Rogge, N., \& Van Puyenbroeck, T. V. (2007). An introduction to 'benefit of the doubt' composite indicators. Social Indicators Research, 82(1), 111-145.

3. Cooper, W. W., Seiford, L. M., \& Tone, K. (2000). Data Envelopment Analysis. Kluwer Academic Publishers, Boston.

4. Farell, M. J. (1957). The Measurement of Productive Efficiency. Journal of Royal Statistical Society, Series A, 120(3), 253-290.

5. Ivanišević, D., Jakšić, D., \& Korać, N. (2015). Wineyard Atlas, Census of Agriculture 2012 in the Republic of Serbia, Statistical Office of the Republic of Serbia, Belgrade [in Serbian: Иванишевић, Д., Јакшић, Д., \& Кораћ, Н. (2015). ВИНОГРАДАРСКИ АТЛАС, Попис пољопривреде 2012 Пољопривреда у Републици Србији. Републички завод за статистику, Београд].

6. Jakšić, D., Ivanišević, D., Đokić, V., \& Brbaklić-Tepavac, M. (2015). Wine Atlas, Census of Agriculture 2012 in the Republic of Serbia, Statistical Office of the Republic of Serbia, Belgrade [in Serbian: Јакшић, Д., Иванишевић, Д., Ђокић, В., \& Брбаклић-Тепавац, М. (2015). ВИНОГРАДАРСКИ АТЛАС, Попис пољопривреде 2012 - Пољопривреда у Републици Србији. Републички завод за статистику, Београд]. 
7. Jovanović, D., Muhi, B., \& Anđelković, A. (2015). Wineries and Wine Routes as a Tool for the Development of Agritourism in Serbia, Business of tourism, 15, 87-93 [in Serbian: Јовановић, Д., Мухи, Б., \& Анђелковић, А. (2015). Винарије и путеви вина као средство за развој агротуризма у Србији. Туристичко пословање, 15, 87-93].

8. Knežević S., \& Fabris M. (2010). Management of Working Capital and Short-term Liabilities, The Accounting, The Association of Accountants and Auditors of Serbia, Belgrade No. 11- 12, pp. 61-73. [in Serbian: Кнежевић C., \& Фабрис М. (2010). Управљања обртним средствима и краткорочним обавезама. Рачуноводство, Савез рачуновођа и ревизора Србије, Београд, 11-12/2010, 61-73].

9. Koopmans, T. C. (1951). An Analysis of Production as an Efficient Combination of Activities Activity, Analysis of Production and Allocation. Wiley, New York.

10. Lukić, R., Lalić, S., Sućeska, A., Hanić, A., \& Bugarčić, M. (2018). Carbon dioxide emissions in retail food. Economics of Agriculture, 65(2), 859-874.

11. Martić, M. (1999). Data Envelopement Analysis with Applications. Ph.D. Thesis, Faculty of Organizational Sciences, Belgrade [in Serbian: Мартић, M. (1999). Анализа обавијених података са применама. Докторска дисертација, Факултет организационих наука, Београд].

12. Melyn, W., \& Moesen, W. (1991). Towards a synthetic indicator of macroeconomic performance: unequal weighting when limited information is available. Public Economics Research Papers, 17 (1), 1-24.

13. Mitrović, A., Knežević, S., \& Veličković, M. (2015). Ratio analysis specifics of the family dairies' financial statements. Economics of Agriculture, 62(4), 1061-1078.

14. OIV, (2015). Note de conjuncture. Organisation Internationale de la Vigne et du Vin, Avril.

15. Paradi, J., Asmild, M., Aggarwall, V., \& Schaffnit, C. (2004).Combining DEA Window Analysis with the Malmquist Index Approach in a Study of the Canadian Banking Industry. Centre for Management of Technology and Enterprenuership, Toronto.

16. Savić, G. (2012). Comparative Analysis of Efficiency in The Financial Sector. Ph.D. Thesis, Faculty of Organizational Sciences, Belgrade [in Serbian: Савић, Г. (2012). Компаративна анализа ефикасности у финансијском сектору. Докторска дисертација, Факултет организационих наука, Београд].

17. Savić, G., \& Martić, M. (2016). Composite indicators construction by data envelopment analysis: Methodological background. Emerging Trends in the Development and Application of Composite Indicators, 98-126. 
18. Sellers-Rubio, R., \& Alampi-Sottini, V. (2016). The influence of size on winery performance: Evidence from Italy. Wine Economics and Policy 5 (1), $33-41$

19. Sellers-Rubio, R., Alampi-Sottini, V., \& Menghini, S., (2016). Productivity growth in the winery sector: evidence from Italy and Spain. International Journal of Wine Business Research, 28 (1), 59-75.

20. Shen, Y., Ruan, D., Hermans, E., Brijs, T., Wets, G., \& Vanhoof, K. (2011). Modeling qualitative data in data envelopment analysis for composite indicators. International Journal and System Assurance and Engineering Management, 2(1), 21-30.

21. UNDP. (2000). Human Development Report 2000. UNDP. United Nations Development Program. 